\title{
Fermentative Production of Polyhydroxyalkanoates (PHAs) from Glycerol by Zobellella taiwanensis Azu-IN1
}

\author{
Mohamed Ali Abdel-Rahman ${ }^{\S}$, Said El-Sayed Desouky ${ }^{\S}$, Mohamed Salah Azab, Mahmoud E. Esmael \\ Botany and Microbiology Department, Faculty of Science (Boys branch), Al-Azhar University, P.N.:11884, Nasr City, Cairo, Egypt.
}

\begin{tabular}{l}
\hline ARTICLE INFO \\
\hline Article history: \\
Received on: $10 / 07 / 2017$ \\
Accepted on: $24 / 08 / 2017$ \\
Available online: $30 / 10 / 2017$ \\
\hline
\end{tabular}

Key words:

Bioplastic; PHA-production; fedbatch fermentation, glycerol; Zobellella taiwanensis.

\begin{abstract}
Polyhydroxyalkalonates (PHAs) are biodegradable thermoplastics that are receiving immense attention as an alternative to petroleum derived plastics. The present study aimed to produce PHA using cheap and ecofriendly biodiesel waste glycerol as a substrate. Several PHA-producing bacterial isolates were isolated from different environmental samples and their efficacy for PHA production was assessed. Isolate Azu-IN1 showed the highest PHA production and was identified as Zobellella taiwanensis Azu-IN1 using 16S rRNA gene sequence and biochemical characterization. Factors affecting PHA production were optimized in batch fermentations. Supplementation of ammonium chloride as nitrogen source, methanol as an auxiliary carbon source, and agitation rate are the main limiting factors affecting PHA production. Maximum PHA production of $2.65 \mathrm{~g} / \mathrm{L}$ at recovery yield of $50.3(\%), w / w)$ was achieved after $36 \mathrm{~h}$ in batch fermentation using optimized medium. Enhanced PHA production of $3.73 \mathrm{~g} / \mathrm{L}$ with recovery yield of $61.7 \%(w / w)$ was obtained in fed batch fermentation. The characteristics of extracted PHA were analyzed using Fourier Transform Infrared Spectroscopy (FTIR) ${ }^{1} \mathrm{H}$ and ${ }^{13} \mathrm{C}$ Nuclear Magnetic Resonance (NMR) spectroscopy. This is the first report on accumulation of PHA by Zobellella taiwanensis using glycerol as the sole carbon source.
\end{abstract}

\section{INTRODUCTION}

A wide variety of petroleum-based synthetic polymers of approximately 187 million tons are annually produced globally and remarkable amounts of these polymers are deposited into the environment as non-biodegradable waste materials [1]. Besides, their incineration generates noxious compounds and elevates the atmospheric carbon dioxide level, causing environmental problems such as global warming [2].

Thus, replacement of conventional petroleum-derived polymers with biopolymers such as polylactide, aliphatic polyesters and PHAs that possess similar physicochemical properties as conventional plastics is of utmost importance [3].

Amongst biopolymer, PHAs are more promising biodegradable plastics due to their inherent biodegradability, sustainability and environment-friendly properties [4]. It has several applications including packaging, paper coatings,

* Corresponding Author

Email: mohamedali @ kyudai.jp

${ }^{\S}$ These authors contributed equally to this work. nonwoven fabrics, adhesives, moulded goods, films and performance additives [5].

PHAs are biogenic polyesters that can be accumulated in microbial cultures under unbalanced growth conditions. These polymers are formed as intracellular hydrophobic inclusions of carbon and energy storage compounds in the cytoplasm [6]. PHAs are generally divided into two groups, short-chain-length (SCL) and medium-chain-length (MCL) PHAs. SCL-PHAs consist of (R)-hydroxyalkanoates of $\mathrm{C}_{3}-\mathrm{C}_{5}$, while MCL-PHAs are comprised of aliphatic and/or aromatic (R)-hydroxyalkanoates of $\mathrm{C}_{6}-\mathrm{C}_{14}$ [7]. The increasing use of PHA polymers, instead of conventional plastics, requires their cost should be competitive. Thus, potent microbial producer, cheap substrates, improved cultivation strategies, and easier downstream processing methods are quintessential [8].

Glycerol is the main by-product for the biodiesel production of about $10 \%(\mathrm{v} / \mathrm{v})$ of the volume of biodiesel. The global biodiesel market is expected to produce 45,291 million liters by 2020 , representing a CAGR of $10.1 \%$ during 2009 to 2020 (http://www.altenergymag.com/). Each ton of biodiesel produced generates co-production of approximately $100 \mathrm{~kg}$ crude 
glycerol. Due to this large production, the price of glycerol has sharply dropped, which makes it an interesting cheap source for microbial production of PHAs $[9,10]$. In addition, to gain sustainability of biodiesel industry, it is necessary to find an alternative feasible solution and effective approaches for utilization of waste glycerol into value-added products.

Therefore, the present study aimed to isolate, screen and characterize PHA-producing bacteria from different environmental sources for their ability to produce PHA from glycerol as low cost carbon source. We identified novel PHA producing bacterial strain and optimized its production in different fermentation modes. Furthermore, the characterization of the extracted PHA was performed using different spectroscopy techniques (NMR, FTIR).

\section{MATERIALS AND METHODS}

\subsection{Isolation sources and medium}

Different sites were selected from different localities of Egypt for bacterial isolation. The solid samples collected include soils collected from field, gas station, factory of leather production, chemical paint factory, and wastes from vegetable processing company. Additionally, liquid samples were also collected including oil contaminated water, sewage contaminated water, sea water and molasses. One gram or $1 \mathrm{ml}$ of isolation samples was inoculated into enrichment culture and incubated for $72 \mathrm{~h}$ at $37^{\circ} \mathrm{C}$ for bacterial isolation. Enrichment medium (mineral salt medium [MSM] $)$ consist of $(\mathrm{g} / \mathrm{L}) ; \mathrm{Na}_{2} \mathrm{HPO}_{4} 12 \mathrm{H}_{2} \mathrm{O}, 9.0 ; \mathrm{KH}_{2} \mathrm{PO}_{4}, 1.5$; $\mathrm{MgSO}_{4} .7 \mathrm{H}_{2} \mathrm{O}, 0.2 ; \mathrm{NH}_{4} \mathrm{Cl}, 1.0 ; \mathrm{CaCl}_{2} .2 \mathrm{H}_{2} \mathrm{O}, 0.02 ; \mathrm{Fe}(\mathrm{III}) \mathrm{NH}_{4}-$ Citrate, 0.0012; and $1 \mathrm{ml}$ of trace elements solution containing (g/L): EDTA, 50.0; $\mathrm{FeCl}_{3}, 8.3 ; \mathrm{ZnCl}_{2}, 0.84 ; \mathrm{CuCl}_{2} .2 \mathrm{H}_{2} \mathrm{O}, 0.13$; $\mathrm{CoCl}_{2} \cdot 6 \mathrm{H}_{2} \mathrm{O}, 0.1 ; \mathrm{MnCl}_{2} \cdot 6 \mathrm{H}_{2} \mathrm{O}, 0.016 ; \mathrm{H}_{3} \mathrm{BO}_{4}, 0.1$. Glycerol was supplemented at $2 \%(v / v)$ as sole carbon source. The $\mathrm{pH}$ of the medium was adjusted to 7.0 using $1 \mathrm{~N} \mathrm{NaOH}$ and $1 \mathrm{~N} \mathrm{HCl}$.

\subsection{Screening tests of PHA-producing isolates}

Primary screening of PHA-producing microorganisms was done by viable-colony staining method using fluorescent dye (Nile red) at $0.5 \mu \mathrm{g} / \mathrm{mL}$ of solid medium as described by Spiekermann et al., [11]. Pure isolates were streaked onto agar plates and incubated at $37^{\circ} \mathrm{C}$ for $72 \mathrm{~h}$. Then, the bacterial colonies were analyzed by exposing to UV light at $312 \mathrm{~nm}$ to detect PHAaccumulation that emit fluorescent. For secondary screening, selected bacterial isolates were cultivated in mineral salt liquid medium supplemented with $2 \%(v / v)$ glycerol then incubated for $72 \mathrm{~h}$ at $37^{\circ} \mathrm{C}$ and $150 \mathrm{rpm}$. The polymers were extracted and quantified.

\subsection{Identification of selected isolate}

Morphological, physiological and biochemical properties of the most potent isolate (Azu-IN1) were examined as described by Abdel-Rahman [12]. Then the identity of bacterial isolate was confirmed based on $16 \mathrm{~S}$ rDNA sequence analysis using universal primers, 27f (5-GAGTTTGATCACTGGCTCAG-3) and 1492r (5TACGGCTACCTTGTTACGACTT-3). The PCR products were sequenced by Sigma Company (Egypt) using ABI 3730xl DNA sequencer. The 16S rRNA gene sequence was compared against the GenBank database using the NCBI BLAST program. Multiple sequence alignment was done using ClustalX 1.8 software package and a phylogenetic tree was constructed by the neighbor joining method using MEGA (Version 6.1) software. The confidence level of each branch (1,000 repeats) was tested by bootstrap analysis.

\subsection{Factors affecting PHA production by strain Azu-IN1}

The following factors were investigated for optimization of PHA production. The deduced optimal conditions resulted from each experiment was taken in consideration in the next experiment. Samples were withdrawn periodically and analyzed for DCW, PHA production and residual glycerol.

For optimal glycerol concentration, different concentrations of glycerol were applied (viz., 0.5, 1, 2, 3, 4, 5 and $10 \%$ ) to production media. Strain Azu-IN1 was inoculated at $10 \%(v / v)$ and incubated at $37^{\circ} \mathrm{C}$ and $150 \mathrm{rpm}$. To determine the best nitrogen source; ammonium chloride in the basal MSM-glycerol medium was replaced at equimolecular weight with organic (peptone and yeast), or inorganic (ammonium chloride, ammonium sulphate, sodium nitrate and di-ammonium hydrogen orthophosphate) nitrogen sources, separately. Strain was inoculated at $10 \%(\mathrm{v} / \mathrm{v})$ and incubated at $37^{\circ} \mathrm{C}$ and $150 \mathrm{rpm}$. To determine optimal ammonium chloride concentration, different concentrations of ammonium chloride (viz., 0.5, 1, 1.5, 2, 2.5, 3 and $4 \mathrm{~g} / \mathrm{L}$ ) were supplemented to basal MSM-glycerol and sterilized. Strain was inoculated at $10 \%(v / v)$ and incubated at $37^{\circ} \mathrm{C}$ and $150 \mathrm{rpm}$ for 36 h.

To determine optimal $\mathrm{pH}$ value, buffer solutions (citrate phosphate, phosphate and borax buffer) were used for medium preparations. Different $\mathrm{pH}$ values (viz., 5, 6, 6.5, 7, 7.5, 8, and 9) were used without $\mathrm{pH}$ control during fermentation. The media were filter sterilized. After inoculation of strain Azu-IN1 at $8 \%(v / v)$, the media were incubated at $37^{\circ} \mathrm{C}$ and $150 \mathrm{rpm}$ for $72 \mathrm{~h}$. To investigate the optimal agitation rate, fermentation media were prepared with the optimal nutritional factors optimized previously. Then inoculated and incubated at different agitation rates (viz., 0 [static], 50, 150, 200 and $250 \mathrm{rpm}$ ). To study the effect of auxiliary carbon sources; methanol, ethanol, sodium acetate, acetic acid, sodium citrate, olive oil, corn oil, paraffin oil, sesame oil, and soy oil were supplemented separately at $0.5 \%$ to the previously optimized MSM-glycerol (1\%) media. Media were inoculated at $8 \%(v / v)$ and incubated at $37{ }^{\circ} \mathrm{C}$ and $200 \mathrm{rpm}$.

\subsection{Fed-batch fermentation}

Fed batch fermentation was carried out in $250 \mathrm{ml}$ Erlenmeyer flask with optimized MSM containing glycerol $(1 \%, v / v)$, methanol $(0.5 \%, v / v)$ and ammonium chloride $(0.2 \%, w / v)$ and incubated at $37{ }^{\circ} \mathrm{C}$ and $200 \mathrm{rpm}$. $\mathrm{pH}$ was adjusted to 6.5 during fermentation. Feedings were supplemented with different strategies (different feeding at various times). First, feeding was performed after $36 \mathrm{~h}$ either by addition of glycerol at $1 \%(v / v)$ [fed batch A] or glycerol at $1 \%(\mathrm{v} / \mathrm{v})$ plus ammonium chloride at $0.1 \%$ $(w / v)$ [fed batch B]. Second, feeding was carried out after $24 \mathrm{~h}$ 
with glycerol at $0.5 \%(v / v)$ plus ammonium chloride at $0.05 \%$ $(w / v)$ [fed batch C] or glycerol at $0.5 \%(v / v)$ plus ammonium chloride at $0.05 \%(w / v)$ plus phosphorus at $(0.075 \%, w / v)$ [fed batch D].

\subsection{Analytical methods}

Cell growth was monitored by measuring the optical density at $600 \mathrm{~nm}$ using spectrophotometer (M-ETKAL-721 Spectrophotometer). Culture medium was centrifuged at 10,000 $\mathrm{rpm}$, at $4^{\circ} \mathrm{C}$ for $5 \mathrm{~min}$ and the cell pellet was washed with distilled water. The cell pellet was harvested by centrifugation and dried at $105^{\circ} \mathrm{C}$ overnight till constant weight was obtained. Cell mass concentration was determined by the standard calibration curve between $\mathrm{OD}_{600}$ and cell dry weight. Glycerol concentration was assayed using glycerol detection method combining the Malaprade reaction and the Hantzsch reaction as described by Kuhn et al., [13].

PHA extraction: bacterial cells were harvested by centrifugation at $10000 \mathrm{rpm}$ for 10 minutes. The pellet was then treated with sodium hypochlorite solution $(4 \% \mathrm{w} / \mathrm{v})$ and incubated at $37^{\circ} \mathrm{C}$ for $1 \mathrm{~h}$ and again centrifuged at $5000 \mathrm{rpm}$ for $15 \mathrm{~min}$. The pellet was then washed with distilled water, and acetone for washing and extraction, respectively. After washing, the pellet was dissolved in $5 \mathrm{~mL}$ of boiling chloroform and allowed to evaporate [14].

PHA assay: Sample containing PHA polymer in chloroform was transferred to a clean test tube, allowing chloroform to evaporate and $10 \mathrm{ml}$ of concentrated $\mathrm{H}_{2} \mathrm{SO}_{4}$ was added. The tube is capped with a glass marble and heated for $10 \mathrm{~min}$ at $100^{\circ} \mathrm{C}$ in a water bath. After cooling, the solution was transferred to a silica cuvette and the absorbance at $235 \mathrm{~nm}$ was measured against a sulfuric acid blank using UV Spectrophotometric (JENWAY 6305 Spectrophotometer). Standard curve was established with PHB concentrations ranging from $0.5-3.5 \mathrm{mg} / \mathrm{ml}$.

\subsection{Production kinetics}

Fermentation kinetic parameters were studied by calculating the biomass yield related to substrate (glycerol) consumption $Y_{\mathrm{X} / \mathrm{S}}$ $(\mathrm{g} / \mathrm{g})$, product recovery yield with respect to cell biomass $Y_{\mathrm{P} / \mathrm{X}}(\%$, $\mathrm{g} / \mathrm{g})$, product yield with respect to substrate consumption $Y_{\mathrm{P} / \mathrm{S}}(\mathrm{g} / \mathrm{g})$, and volumetric productivity $P_{\mathrm{PHA}}(\mathrm{g} / \mathrm{L} / \mathrm{h})$, product yield to the fermentation time $(h)$.

\subsection{Characterization of PHA}

\subsubsection{Transform-infrared Spectroscopy (FTIR):}

The chemical structure of the extracted PHA was analyzed by Fourier Transform Infrared (FTIR) spectroscopy at Faculty of pharmacy, Al-Azhar University, Cairo, Egypt. The biopolymer was dissolved in chloroform and added to potassium bromide $(\mathrm{KBr})$ pellets and then the solvent was evaporated. The infrared spectra of the samples were recorded in the wave number range from 500 to $4000 \mathrm{~cm}^{-1}$ using a Perkin Elmer FTIR spectrophotometer (NICOLET-IR 200).

\subsubsection{NMR spectroscopy for PHA analysis}

The ${ }^{1} \mathrm{H}$ - NMR and ${ }^{13} \mathrm{C}$ - NMR spectra were recorded at $25^{\circ} \mathrm{C}$ with Mercury $400 \mathrm{MHz}$ Spectrometer equipped with ${ }^{1} \mathrm{H}$ and ${ }^{13} \mathrm{C}$ dual probe to study the structural elucidation. $20 \mathrm{mg}$ of the extracted $\mathrm{PHB}$ was dissolved in $\mathrm{CDCl}_{3}$ and subjected to analysis.

\section{RESULTS}

\subsection{Isolation and screening of PHA-producers}

Ninety-six bacterial isolates were obtained from the different environmental sampling sites. Out of these isolates, 14 isolates showed bright fluorescence on agar plates upon exposing to UV light at wavelength of $312 \mathrm{~nm}$. This indicated that these isolates have ability to produce PHA, therefore, further these isolates were subjected to PHA quantification screening by cultivating on MSM supplemented with glycerol. PHA content was estimated and compared. As shown in Table (1), 12 isolates showed PHA production ranged lower than $1.0 \mathrm{~g} / \mathrm{L}$. On the other hand, isolate In-N3 produced $1.11 \mathrm{~g} / \mathrm{L}$ of PHA while PHA concentration of 1.37 $\mathrm{g} / \mathrm{L}$ was produced by isolate Azu-IN1. The Azu-IN1strain was observed to be highest PHA producer among all other isolates and thus one of the potent candidate for further studies.

Table 1: Quantitative screening test by 14 selected isolates for PHA production using $2 \%(v / v)$ glycerol.

\begin{tabular}{cc}
\hline Isolates code & PHA (g/L) \pm SD \\
\hline WV1 & $0.180 \pm 0.002$ \\
BS 2 & $0.160 \pm 0.002$ \\
A1 & $0.110 \pm 0.009$ \\
AZU-A2 & $0.190 \pm 0.007$ \\
AKS 1 & $0.210 \pm 0.002$ \\
AKS 5 & $0.220 \pm 0.003$ \\
SH5 & $0.390 \pm 0.002$ \\
SH7 & $0.410 \pm 0.011$ \\
AD 3 & $0.300 \pm 0.004$ \\
FS1 & $0.160 \pm 0.004$ \\
FS5 & $0.170 \pm 0.006$ \\
Azu-IN1 & $1.37 \pm 0.008$ \\
In-N3 & $1.11 \pm 0.010$ \\
AZS3 & $0.190 \pm 0.008$ \\
\hline
\end{tabular}

Table 2: A summary of the morphological, physiological and biochemical characteristics of the most potent bacterial isolate Azu-IN1.

\begin{tabular}{lcll}
\hline Test & Result & Test & Result \\
\hline Gram stain & - & $\underline{\text { Sugar }}$ & \\
Shape & & formentations: & \\
KOH & + & Glucose & + \\
Catalase & + & Xylose & + \\
Citrate utilization & + & Malactose & - \\
Urea hydrolysis & + & Fructose & + \\
Pectin hydrolysis & - & Mannitol & + \\
Cellulose hydrolysis & - & Sucrose & - \\
Gelatin hydrolysis & - & Lactose & - \\
Starch hydrolysis & \pm & Inositol & - \\
Growth at different & & Myo-inositol & - \\
NaCl conc.: & & & \\
\multicolumn{1}{c}{$2 \%$} & + & Cellobiose & - \\
$5 \%$ & \pm & Inulin & + \\
$10 \%$ & - & & \\
\hline
\end{tabular}




\subsection{Identification of isolate Azu-IN1}

Identification of isolate Azu-IN1 was performed by studying its morphological (Gram's reaction, shape), and biochemical characteristics (Table 2). The strain Azu-IN1 was Gram-negative with rod shape and was catalase-positive. It can grow at high salt concentration [up to $5 \%$ sodium chloride]. The isolate showed capability of urea hydrolysis and citrate utilization. However, it could not utilize cellulose, gelatin or pectin. This isolate could ferment different sugars including glucose, xylose, maltose, fructose, mannitol, and inulin but was not able to ferment galactose, sucrose, lactose, inositol, myo-inositol, and cellobiose.

The 16S rRNA gene sequence of the Azu-IN1 isolate showed the highest similarity at $99.0 \%$ with Zobellella taiwanensis strain DN-7 [accession number, KM361042], strain ZT1 [accession numbers, NR_043630.1 and DQ195676.1]. The phylogenetic tree was constructed using strain Azu-IN1 and other closely related type strains as depicted in Fig. (1). Therefore, the strain was identified as Zobellella taiwanensis Azu-IN1. 16S rRNA gene sequence was deposited in GenBank with the accession number MF422186.

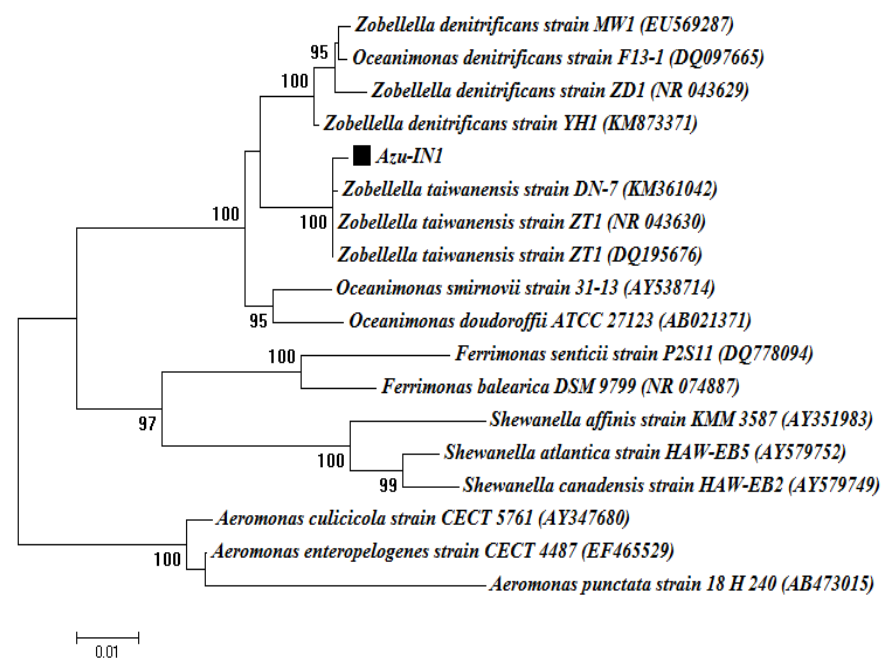

Fig. 1: Phylogenetic analysis of 16S rRNA sequences of the bacterial isolates (Azu-IN1) with the sequences from NCBI. Symbol $\mathbf{m}$ refers to 16S rRNA gene fragments retrieved from this study. The analysis was conducted with MEGA 6 using neighbor joining method. Bar 0.1 nucleotide substitutions per position.

\subsection{Factors affecting PHA production \\ 3.3.1 Effect of glycerol concentrations}

Strain Azu-IN1 was cultivated in MSM medium containing different glycerol concentrations $(0.5-10 \%, v / v)$. Almost comparable DCW was obtained at all tested glycerol concentrations (Fig. 2). The highest PHA production of $1.96 \mathrm{~g} / \mathrm{L}$ with yield of $0.341 \mathrm{~g} / \mathrm{g}$-consumed glycerol and recovery yield of $46.30 \%(w / w)$ was obtained using $1.0 \%$ glycerol after $72 \mathrm{~h}$ that resulted in low productivity at $0.027 \mathrm{~g} / \mathrm{L} / \mathrm{h}$ (Fig. 2B). Beyond this concentration $(>1 \%)$, decline in PHA accumulation was obtained. This shows that glycerol does not inhibit cell growth but inhibits product formation. From the above results, concentration $1.0 \%$ of glycerol was considered as the best concentration for accumulation PHA by strain Azu-IN1.

(A)

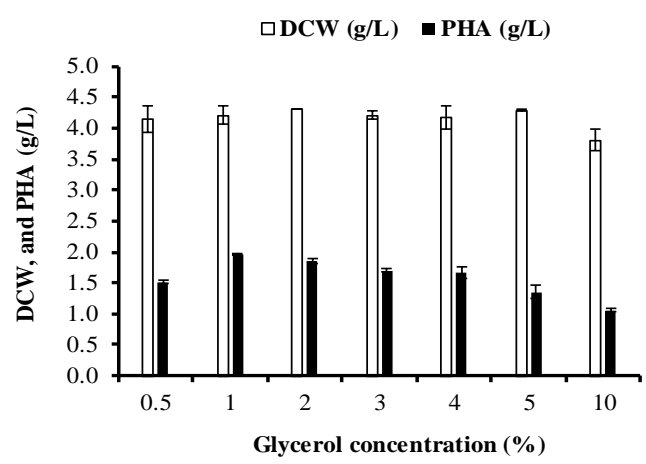

(B)

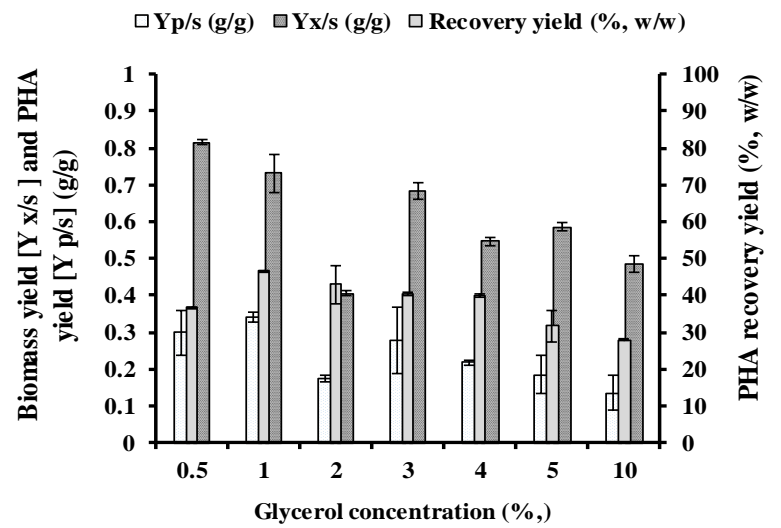

Fig. 2: Effect of different concentrations of glycerol on (A) cell growth (Dry cell weight), PHA production, and (B) Biomass yield, PHA yield and PHA recovery by Zobellella taiwanensis Azu-IN1 in batch fermentations.

Table 3: Effect of different nitrogen sources on PHA production from glycerol by Zobellella taiwanensis Azu-IN1 after $72 \mathrm{~h}$.

\begin{tabular}{|c|c|c|c|c|c|c|c|}
\hline $\begin{array}{l}\text { Nitrogen } \\
\text { sources }\end{array}$ & $\begin{array}{l}\text { Max. DCW } \\
(g / L) \pm \text { SD }\end{array}$ & $\begin{array}{l}\text { Residual } \\
\text { glycerol } \\
(\mathrm{g} / \mathrm{L}) \pm \mathrm{SD}\end{array}$ & $\begin{array}{l}Y_{(x / s)}{ }^{\mathrm{a}} \\
(\mathrm{g} / \mathrm{g})\end{array}$ & $\begin{array}{l}\text { PHA }(g / L) \\
\pm \text { SD }\end{array}$ & $\begin{array}{l}\text { Recovery } \\
\text { yield \% }(w / w)\end{array}$ & $\begin{array}{l}Y_{(p / s)}{ }^{b} \\
(g / g)\end{array}$ & $\boldsymbol{P}_{(\mathrm{g} / \mathrm{L} / \mathrm{h})}^{\mathrm{c}}$ \\
\hline Ammonium sulfate & $3.22 \pm 0.040$ & $2.19 \pm 0.170$ & 0.320 & $1.57 \pm 0.036$ & 48.88 & 0.156 & 0.022 \\
\hline Ammonium chloride & $4.33 \pm 0.072$ & $1.38 \pm 0.048$ & 0.398 & $2.01 \pm 0.014$ & 46.52 & 0.185 & 0.028 \\
\hline Yeast extract & $2.60 \pm 0.108$ & $5.80 \pm 0.030$ & 0.403 & $0.86 \pm 0.012$ & 33.00 & 0.133 & 0.012 \\
\hline Peptone & $2.62 \pm 0.024$ & $1.95 \pm 0.047$ & 0.254 & $0.88 \pm 0.036$ & 33.76 & 0.086 & 0.012 \\
\hline Sodium Nitrate & $1.73 \pm 0.018$ & $1.05 \pm 0.022$ & 0.154 & $0.48 \pm 0.019$ & 27.63 & 0.043 & 0.007 \\
\hline
\end{tabular}

${ }^{\mathrm{a}}$ Yield of biomass based on substrate consumed; ${ }^{\mathrm{b}}$ Yield of PHA based on substrate consumed; ${ }^{\mathrm{c}}$ Productivity of PHA. 
Different organic and inorganic nitrogen sources were investigated as shown in Table 3. Maximum DCW of $4.33 \mathrm{~g} / \mathrm{L}$ with highest PHA production of $2.01 \mathrm{~g} / \mathrm{L}$ was obtained with ammonium chloride after $72 \mathrm{~h}$ compared to other nitrogen sources tested. With ammonium chloride, the PHA recovery yield at 46.5 $\%(w / w)$, PHA yield of $0.185 \mathrm{~g} / \mathrm{g}$-consumed sugar and productivity of $0.028 \mathrm{~g} / \mathrm{L} / \mathrm{h}$ were achieved. Ammonium sulfate and diammonium hydrogen ortho-phosphate attained high PHA production at 1.57 and $1.45 \mathrm{~g} / \mathrm{L}$, respectively. On the other hand, the supplementation of organic nitrogen sources (peptone, yeast extract) or sodium nitrate showed a negative effect on PHA accumulation by strain Azu-IN1.

High DCW (ranging from 4.81-4.85 g/L) was achieved after $72 \mathrm{~h}$ using 2-4.0 $\mathrm{g} / \mathrm{L}$ of ammonium chloride in the fermentation medium. However, the maximal PHA production of $2.30 \mathrm{~g} / \mathrm{L}$ and the highest recovery yield of $49.76 \%,(w / w)$ was obtained using 1 $\mathrm{g} / \mathrm{L}$ ammonium chloride after $72 \mathrm{~h}$ (Table 4). As a results, ammonium chloride at concentration $(1.0 \mathrm{~g} / \mathrm{L})$ was considered as the best concentration for PHA production by strain Azu-IN1.

Table 4: Effect of different concentrations of ammonium chloride on PHA production from glycerol by Zobellella taiwanensis Azu-IN1.

\begin{tabular}{|c|c|c|c|c|c|c|c|}
\hline $\begin{array}{l}\text { Ammonium } \\
\text { chloride } \\
\text { conc. } \\
\text { (g/L) }\end{array}$ & $\begin{array}{c}\text { Max. } \\
\text { DCW }(g / L) \\
\pm \text { SD }\end{array}$ & $\begin{array}{c}\text { Residual } \\
\text { glycerol } \\
(\mathrm{g} / \mathrm{L}) \pm \mathrm{SD}\end{array}$ & $\begin{array}{c}Y_{(x / s)}{ }^{a} \\
(\mathrm{~g} / \mathrm{g})\end{array}$ & $\begin{array}{c}\text { PHA (g/L ) } \\
\quad \pm \text { SD }\end{array}$ & $\begin{array}{c}\text { Recovery } \\
\text { yield \% } \\
(w / w)\end{array}$ & $\begin{array}{c}Y_{(p / s)}{ }^{b} \\
(g / g)\end{array}$ & $\boldsymbol{P}_{(\mathrm{g} / \mathrm{L} / \mathbf{h})} \mathrm{c}$ \\
\hline 0.5 & $3.92 \pm 0.027$ & $7.23 \pm 0.599$ & 0.744 & $1.35 \pm 0.007$ & 34.55 & 0.257 & 0.019 \\
\hline 1.0 & $4.62 \pm 0.030$ & $1.59 \pm 0.374$ & 0.424 & $2.30 \pm 0.009$ & 49.76 & 0.211 & 0.032 \\
\hline 1.5 & $4.76 \pm 0.075$ & $2.64 \pm 0.427$ & 0.621 & $2.27 \pm 0.010$ & 47.73 & 0.296 & 0.032 \\
\hline 2.0 & $4.81 \pm 0.055$ & $2.92 \pm 0.015$ & 0.502 & $2.00 \pm 0.018$ & 41.56 & 0.209 & 0.028 \\
\hline 2.5 & $4.81 \pm 0.028$ & $1.12 \pm 0.034$ & 0.416 & $2.00 \pm 0.016$ & 41.55 & 0.173 & 0.028 \\
\hline 3.0 & $4.83 \pm 0.056$ & $3.77 \pm 0.153$ & 0.554 & $1.84 \pm 0.053$ & 38.13 & 0.211 & 0.026 \\
\hline 4.0 & $4.85 \pm 0.025$ & $5.60 \pm 0.429$ & 0.703 & $1.48 \pm 0.039$ & 30.40 & 0.214 & 0.020 \\
\hline
\end{tabular}

${ }^{\mathrm{a}}$ Yield of biomass based on substrate consumed; ${ }^{\mathrm{b}}$ Yield of PHA based on substrate consumed; ${ }^{\mathrm{c} P r o d u c t i v i t y ~ o f ~ P H A ~}$

\subsubsection{Effect of $\mathbf{p H}$ values}

The influence of $\mathrm{pH}$ (5.0-9.0) on PHA accumulation was investigated using the previously optimized conditions during fermentation. As shown in Fig. $3 \mathrm{~A}$, the DCW is almost comparable at a wide range of $\mathrm{pH}$ values $(6.0-8.0)$ that ranged 3.41-5.27 $\mathrm{g} / \mathrm{L}$ after $72 \mathrm{~h}$ that is similar to that obtained after $48 \mathrm{~h}$ (3.01-5.26 g/L). On the other hand, PHA production, recovery yield and $Y_{\mathrm{p} / \mathrm{s}}$ value had maximum values at $\mathrm{pH} 6.5$ with $2.36 \mathrm{~g} / \mathrm{L}$, $44.78 \%(w / w) 0.232 \mathrm{~g} / \mathrm{g}$, respectively (Fig. $3 \mathrm{~B}$ and C). As result, initial $\mathrm{pH} 6.5$ was selected for further investigations.

\subsubsection{Effect of agitation rate}

The influence of agitation rate $(0.0-250 \mathrm{rpm})$ on DCW/PHA production by strain Azu-IN1 were investigated as shown in Fig. (4). It was found that, there is a positive correlation between agitation rate and DCW /PHA production by strain Azu-IN1. The best PHA production was obtained at agitation rate of $200 \mathrm{rpm}$ after $36 \mathrm{~h}$ at $2.34 \mathrm{~g} / \mathrm{L}$ and $46.07 \%(w / w)$, respectively. Therefore, an agitation rate of $200 \mathrm{rpm}$ was considered as the optimal agitation rate PHA fermentation by Azu-IN1.
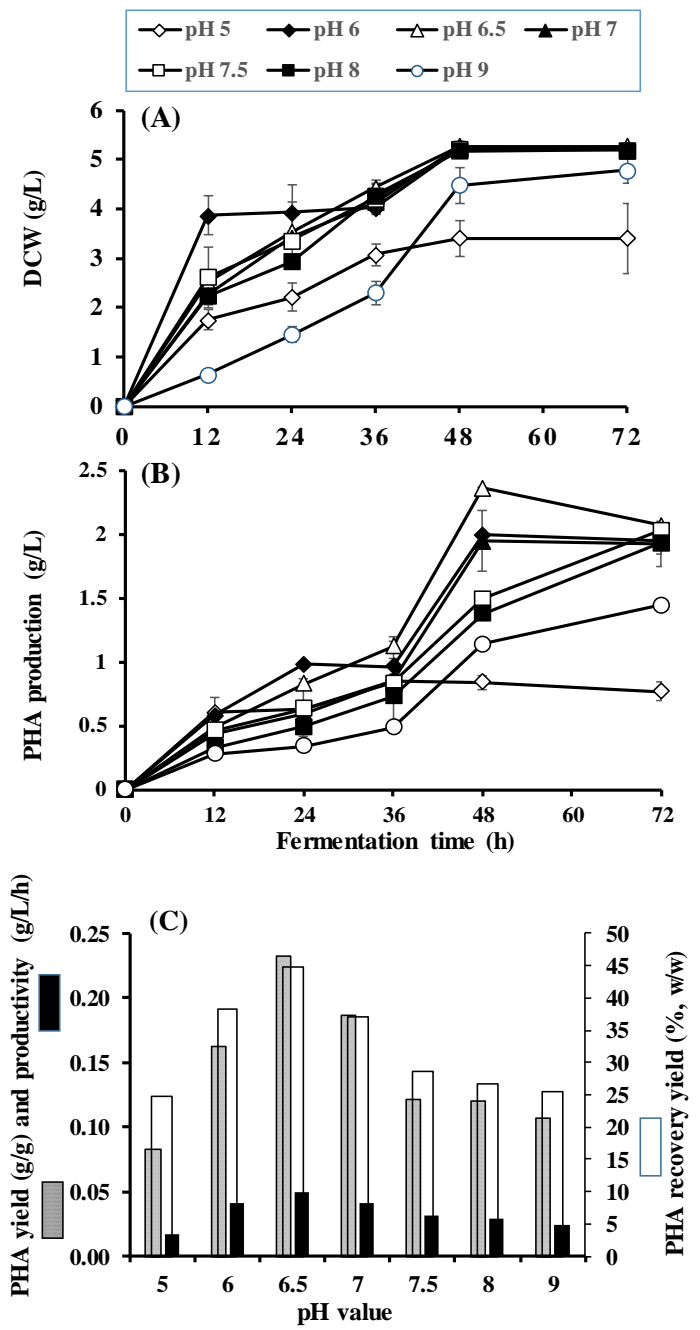

Fig. 3: Effect of $\mathrm{pH}$ value on PHA fermentation from glycerol by Zobellella taiwanensis Azu-IN1 (A) dry cell weight, (B) PHA production, g/L, and (C) PHA yield, productivity and recovery. Data points represent the means and standard deviations of results from 3 independent experiments. The standard deviation is less than that corresponding to the size of the symbol if no error bars are seen.

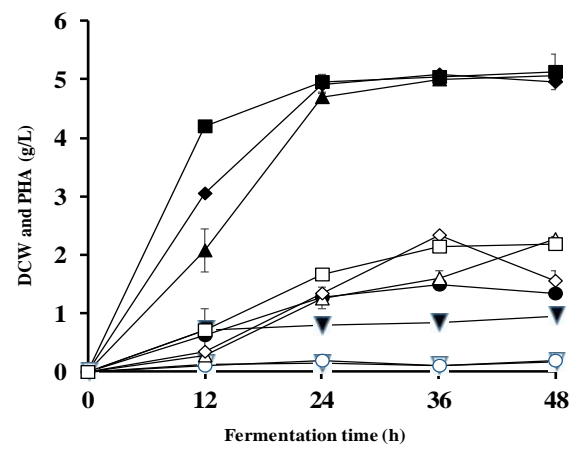

Fig. 4: Effect of different agitation rates on cell growth (dry cell weight and PHA production from glycerol by Zobellella taiwanensis Azu-IN1. Symbols; inverted triangle, $0 \mathrm{rpm}$; circle, $50 \mathrm{rpm}$; triangle, $150 \mathrm{rpm}$; diamond, $200 \mathrm{rpm}$; square, $250 \mathrm{rpm}$. Closed symbols show DCW and open symbols show PHA production $(\mathrm{g} / \mathrm{L})$. Data points represent the means and standard deviations of results from 3 independent experiments. The standard deviation is less than that corresponding to the size of the symbol if no error bars are seen. 


\subsubsection{Effect of auxiliary carbon sources (co-substrates)}

Different additional carbon sources were supplemented separately at $0.5 \%$ to optimized MSM media containing $1 \%$ glycerol $(1.0 \%)$ at $37^{\circ} \mathrm{C}$ and $200 \mathrm{rpm}$. As shown in Table 5, sodium acetate and acetic acid resulted in decreased biomass at $0.75 \mathrm{~g} / \mathrm{L}$ and $1.44 \mathrm{~g} / \mathrm{L}$, respectively after $36 \mathrm{~h}$. Other tested cosubstrates resulted in high cell growth that was ranged 5.07-5.29 $\mathrm{g} / \mathrm{L}$. There is a significant increase in PHA production and recovery yield by supplementations of methanol at $2.66 \mathrm{~g} / \mathrm{L}$, and $50.06 \%$, respectively that is almost $13 \%$ and $4 \%$ increase compared to that produced without any supplementation at 46.07 $\%$, and $2.34 \mathrm{~g} / \mathrm{L}$, respectively. As result, methanol considered as the best auxiliary carbon source for achieving high efficiency fermentation of PHA.

Table 5: Effect of different auxiliary carbon sources on PHA production from glycerol by Zobellella taiwanensis Azu-IN1 after $36 \mathrm{~h}$.

\begin{tabular}{|c|c|c|c|c|c|c|c|}
\hline $\begin{array}{l}\text { Different } \\
\text { carbon } \\
\text { sources }\end{array}$ & $\begin{array}{l}\text { Max. DCW } \\
(\mathrm{g} / \mathrm{L}) \pm \text { SD }\end{array}$ & $\begin{array}{l}\begin{array}{l}\text { Residual } \\
\text { glycerol } \\
(\mathrm{g} / \mathrm{L}) \pm \\
\text { SD }\end{array} \\
\end{array}$ & $\begin{array}{l}Y_{(x / s)}{ }^{a} \\
(g / g)\end{array}$ & $\begin{array}{l}\text { PHA }(g / L) \\
\text { SD }\end{array}$ & $\begin{array}{c} \pm \text { Recovery } \\
\quad \text { yield \% } \\
(w / w)\end{array}$ & $\begin{array}{l}Y_{(p / s)}{ }^{b} \\
(g / g)\end{array}$ & $\begin{array}{l}P \cdot P H A \\
(g / L / h)\end{array}$ \\
\hline Methanol & $\begin{array}{c}5.31 \\
\pm 0.007\end{array}$ & $\begin{array}{c}0.84 \pm \\
0.128\end{array}$ & 0.455 & $\begin{array}{c}2.66 \\
\pm 0.009\end{array}$ & 50.06 & 0.228 & 0.074 \\
\hline Ethanol & $\begin{array}{c}5.23 \\
\pm 0.003\end{array}$ & $\begin{array}{c}4.00 \pm \\
0.397\end{array}$ & 0.615 & $\begin{array}{c}2.20 \\
\pm 0.019\end{array}$ & 42.10 & 0.259 & 0.061 \\
\hline $\begin{array}{l}\text { Sodium } \\
\text { citrate }\end{array}$ & $\begin{array}{c}5.13 \\
\pm 0.020\end{array}$ & $\begin{array}{c}2.45 \pm \\
0.135\end{array}$ & 0.511 & $\begin{array}{c}1.66 \\
\pm 0.007\end{array}$ & 32.36 & 0.165 & 0.046 \\
\hline $\begin{array}{l}\text { Sodium } \\
\text { acetate }\end{array}$ & $\begin{array}{c}0.75 \\
\pm 0.185\end{array}$ & $\begin{array}{c}10.11 \pm \\
0.482\end{array}$ & 0.312 & $\begin{array}{c}0.15 \\
\pm 0.002\end{array}$ & 20.63 & 0.064 & 0.004 \\
\hline Acetic acid & $\begin{array}{c}1.44 \\
\pm 0.029\end{array}$ & $\begin{array}{c}9.76 \pm \\
0.382\end{array}$ & 0.525 & $\begin{array}{c}0.19 \\
\pm 0.002\end{array}$ & 13.23 & 0.070 & 0.005 \\
\hline $\begin{array}{c}\text { Caster seed } \\
\text { oil }\end{array}$ & $\begin{array}{c}5.29 \\
\pm 0.027\end{array}$ & $\begin{array}{c}1.96 \pm \\
0.121\end{array}$ & 0.501 & $\begin{array}{c}1.70 \\
\pm 0.007\end{array}$ & 32.11 & 0.161 & 0.047 \\
\hline Corn oil & $\begin{array}{c}5.28 \\
\pm 0.021\end{array}$ & $\begin{array}{l}1.71 \pm \\
0.086\end{array}$ & 0.490 & $\begin{array}{c}0.82 \\
\pm 0.007\end{array}$ & 15.50 & 0.076 & 0.023 \\
\hline Olive oil & $\begin{array}{c}5.29 \\
\pm 0.020\end{array}$ & $\begin{array}{l}1.97 \pm \\
0.108\end{array}$ & 0.503 & $\begin{array}{c}1.38 \\
\pm 0.005\end{array}$ & 26.07 & 0.131 & 0.038 \\
\hline Soy bean oil & $\begin{array}{c}5.19 \\
\pm 0.052\end{array}$ & $\begin{array}{l}2.21 \pm \\
0.075\end{array}$ & 0.504 & $\begin{array}{c}1.85 \\
\pm 0.010\end{array}$ & 35.71 & 0.180 & 0.051 \\
\hline Sesame oil & $\begin{array}{c}5.07 \\
\pm 0.007\end{array}$ & $\begin{array}{l}1.48 \pm \\
0.047\end{array}$ & 0.460 & $\begin{array}{c}1.64 \\
\pm 0.012\end{array}$ & 32.44 & 0.149 & 0.046 \\
\hline Paraffin oil & $\begin{array}{c}5.28 \\
\pm 0.018\end{array}$ & $\begin{array}{l}1.52 \pm \\
0.111\end{array}$ & 0.481 & $\begin{array}{c}0.87 \\
\pm 0.002\end{array}$ & 16.54 & 0.080 & 0.024 \\
\hline
\end{tabular}

${ }^{a}$ Yield of biomass based on substrate consumed; ${ }^{b}$ Yield of PHA based on substrate consumed; 'Productivity of PHA

\subsection{Fed-batch fermentation}

In order to further enhance cell biomass and PHA production by strain Azu-IN1, fed batch fermentations were conducted using different feedings. As shown in Fig. S1, in fed batch A [see supplementary Fig. S1-A], where the feeding with only glycerol $(1 \%)$, cell biomass reached $5.33 \mathrm{~g} / \mathrm{L}$ after $36 \mathrm{~h}$ with a little increase after that and achieving its maximal value of $5.94 \mathrm{~g} / \mathrm{L}$ after $60 \mathrm{~h}$. On the other hand, the accumulation of PHA achieved its maximum value of $3.14 \mathrm{~g} / \mathrm{L}$ with recovery yield of $53.17 \%(\mathrm{w} / \mathrm{w})$ at $84 \mathrm{~h}$.

Conducting similar fermentation with feeding solution of glycerol and ammonium chloride (Fed-batch B, see supplementary Fig. S1-B) have resulted in almost similar DCW of $6.03 \mathrm{~g} / \mathrm{L}$ after 84 h, however, higher accumulation of PHA was obtained achieving its maximal value of $3.24 \mathrm{~g} / \mathrm{L}$ with recovery yield of $54.60 \%(w / w)$ after $60 \mathrm{~h}$.

In another strategy using lower glycerol concentration in feeding solution, fed-Bach $\mathrm{C}$ and $\mathrm{D}$ were conducted. In those fermentations, feeding was intermitted supplied to maintain glycerol concentration at same level. In fed batch $\mathrm{C}$ (see supplementary Fig. S1-C), where the feeding with glycerol $(0.5 \%)$ and ammonium chloride $(0.05 \%)$, maximum production of DCW $5.60 \mathrm{~g} / \mathrm{L}$ after $48 \mathrm{~h}$ with PHA $2.14 \mathrm{~g} / \mathrm{L}$ at $60 \mathrm{~h}$ is lower than obtained with other fed batches tested. In fed batch D (Fig. 5), where the feeding with glycerol $(0.5 \%)$, phosphorus $(0.075 \%$, $\mathrm{w} / \mathrm{v})$, and ammonium chloride $(0.05 \%)$, high PHA was produced at $3.73 \mathrm{~g} / \mathrm{L}$ with recovery yield of $61.65 \%(w / w)$ after $72 \mathrm{~h}$. These result, are higher than the amount of PHA of $2.65 \mathrm{~g} / \mathrm{L}$ and recovery yield of PHA $50.27 \%(w / w)$ obtained with batch process and other fed batch strategies.

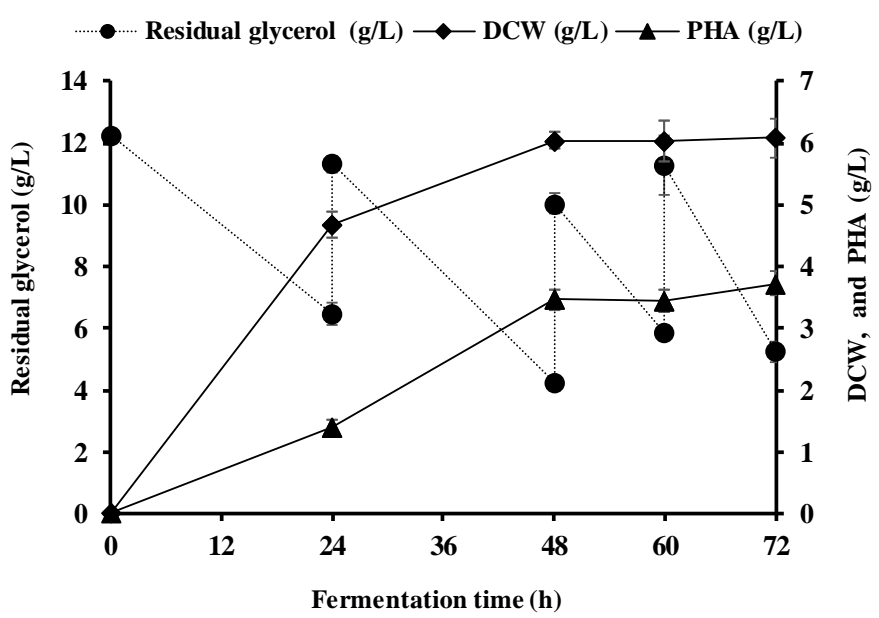

Fig. 5: Fed batches fermentation for PHA production from glycerol by Zobellella taiwanensis Azu-IN1 at $37{ }^{\circ} \mathrm{C}$, initial pH 6.5 and agitation rate 200 $\mathrm{rpm}$. Feeding solution consists of glycerol $(0.5 \%)$, phosphorus $(0.075 \%$, w/v), and ammonium chloride $(0.05 \%)$. Data points represent the means and standard deviations of results from 3 independent experiments. The standard deviation is less than that corresponding to the size of the symbol if no error bars are seen 


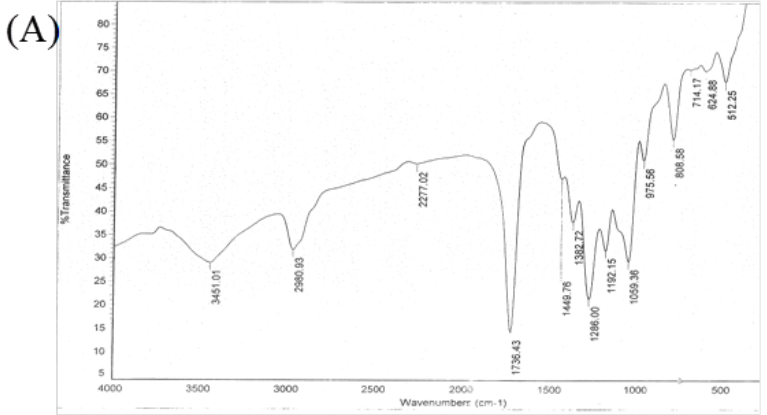

(B)

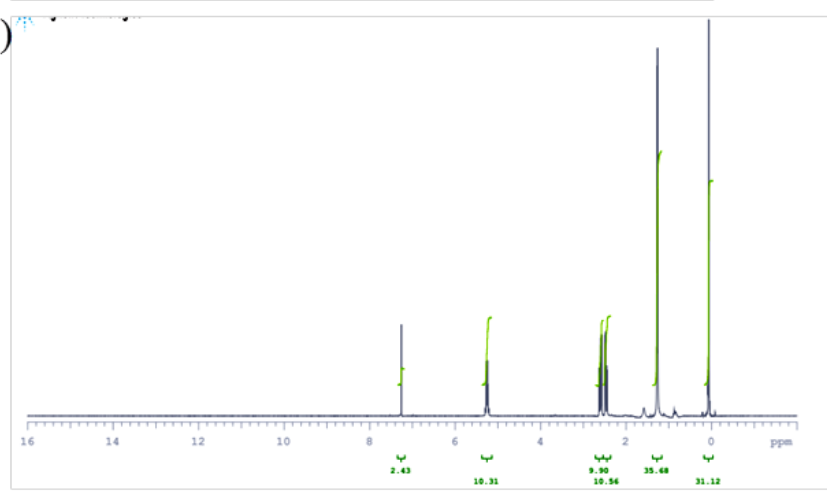

(C)

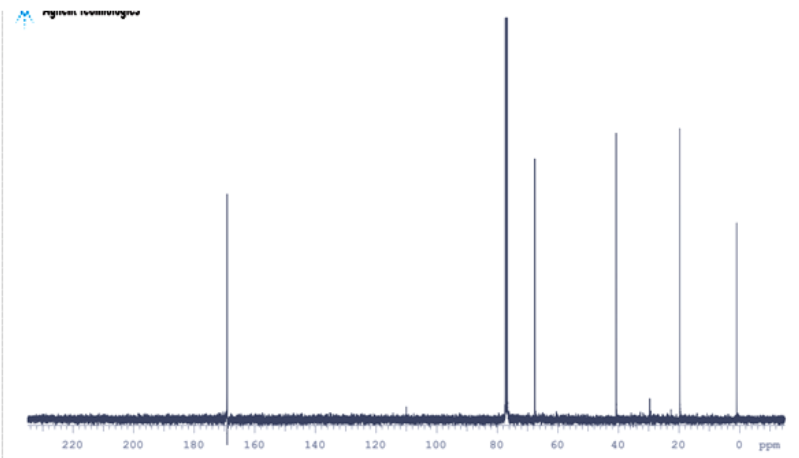

Fig. 6: (A) Fourier transform infrared spectra analysis (B) ${ }^{1} \mathrm{H}$ chemical shifts, (C) ${ }^{13} \mathrm{C}$ chemical shifts of constituent monomers of purified PHA produced by Zobellella taiwanensis Azu-IN1.

\subsection{Characterization of polyhydroxyalkanoates}

The IR spectrum of PHA compound $(\mathrm{KBr}$, vmax $\mathrm{cm}-1)$ by Fourier Transform-Infrared Spectroscopy (FTIR) shown in Fig. 6A, showed absorption bands at $3451 \mathrm{~cm}^{-1}$ (OH stretching), 2980 $\mathrm{cm}^{-1}$ (C-H stretching), $1736 \mathrm{~cm}^{-1}$ (C=O stretching), 1449 and 1286 $\mathrm{cm}^{-1}$ (methylene bending), [15].

${ }^{1} \mathrm{H}-\mathrm{NMR}$ spectrum of PHA compound (Fig. 6B) indicated characteristic signals of PHA, namely a doublet at $1.25 \mathrm{ppm}$, which is attributed to the methyl $\left(\mathrm{CH}_{3}\right)$ group coupled to one proton while a doublet of quadruplet at $2.44 \mathrm{ppm}$ due to the methylene $\left(\mathrm{CH}_{2}\right)$ group adjacent to an asymmetric carbon atom bearing a single proton. The third signal at $5.21 \mathrm{ppm}$, which was attributed to the methine $(\mathrm{CH})$ group.

\section{DISCUSSION}

A biodegradable bioplastic such as aliphatic polyester belongs to the family of PHAs which shows material properties as petrochemical plastics (e.g. polyethylene or polypropylene) but having positive environmental impacts. The major objective of this study was to select potential microbial PHA producers using low cost substrates and optimize the production conditions in different fermentation modes.

In the present study 96 bacterial isolates were isolated from different localities in Egypt. These isolates were analyzed for hydrophobic compounds like PHA inside the cells as previously reported $[11,16]$. Amongst these, 14 isolates showed bright to red fluorescence color and used for quantitate analysis of PHA produced from glycerol as an inexpensive carbon source. Isolate Azu-IN1 could accumulate the highest amount of PHA at $1.37 \mathrm{~g} / \mathrm{L}$ and was selected for characterization. Based on 16S rRNA analysis (Fig. 1), strain Azu-IN1 clustered with the members of the genus Zobellella, showing the highest 16S rDNA gene sequence similarity of $99 \%$ with Zobellella taiwanensis and was identified as Zobellella taiwanensis Azu-IN1. The genus Zobellella is well known for being able to synthetize PHA using different carbon sources [17], but to the authors knowledge, there is no report on PHA production by Zobellella taiwanensis.

The monomer composition of the PHA was determined by FTIR, ${ }^{1} \mathrm{H}$ and ${ }^{13} \mathrm{C}$ Nuclear Magnetic Resonance (NMR) spectroscopy. ${ }^{1} \mathrm{H}$ NMR spectra were collected with a Varian Mercury $400 \mathrm{MHz}$ spectrometer. The data was matched with the published data for same compound [18]. The values of the chemical shifts as well as the assignments of the ${ }^{1} \mathrm{H}$ NMR signals, which appeared in the spectra agree with the authentic PHB sample produced from Aldrich Company, which clearly classified the extracted biopolymer from the isolated strain in the present study as poly-3-hydroxybutyric acid and confirmed by ${ }^{13} \mathrm{C}$ NMR spectrum (Fig. 6C).

Physical and nutritional factors affecting PHA production by strain Azu-IN1 were optimized in batch fermentations. In this study, maximum production of DCW and PHA and high recovery yield of PHA by strain Azu-IN1 achieved with 1\% $(v / v)$ of glycerol, beyond this concentration PHA accumulation was reduced. This might be attributed to substrate inhibition that cause osmotic stress and affect cellular metabolism that decreased enzymatic activities and PHA recovery [17]. The use of $1 \%(v / v)$ glycerol was reported as the optimal concentration for PHA production in Bacillus sphaericus [19], whereas 2\% (v/v) glycerol was reported to be the optimal for PHA production by Pseudomonas mendocina PSU [20], Halomonas sp. SA8 [21], and Pandoraea sp. [22].

Limited nitrogen condition is one of the critical factors affecting PHA synthesis in different bacterial strains. In this study, $1.0 \mathrm{~g} / \mathrm{L}$ of ammonium chloride as nitrogen source positively enhanced the accumulation of PHA amongst other tested sources. A maximum production of PHA $2.30 \mathrm{~g} / \mathrm{L}$ with accumulation of PHA at $49.76 \%(w / w)$ recovery yield after $72 \mathrm{~h}$ were attained. On the other hand, supplementation of organic nitrogen sources leads 
to decreased PHA production. Inorganic chemicals such as ammonia, or ammonium salts are an important for maximizing biomass concentration and PHA accumulation [23]. Ammonium chloride was reported as the best nitrogen source for PHAs production by several researchers [17, 24-26]. Kalaiyezhini and Ramachandran [27] found that ammonium sulphate supported high growth and PHA production from glycerol in Paracoccus denitrificans.

$\mathrm{pH}$ is one of the important factors affecting cell growth, enzymatic activities and product formation. $\mathrm{pH} 6.5$ was found to be optimum for PHA production by strain Azu-IN1 after $48 \mathrm{~h}$. Most studies reported neutral to slightly acidic or slightly alkaline $\mathrm{pH}$ ( $\mathrm{pH}$ 6.0-8.0) is the optimal for PHAs accumulation by several bacterial strains [27-30].

In this study, agitation rate is reported to be limiting factor for PHA accumulation by strain Azu-IN1. The lowest growth rate was achieved at static condition, while a significant increase in growth rate accompanied by accumulation of PHA was gradually increased by increasing agitation rate up to $200 \mathrm{rpm}$ after $36 \mathrm{~h}$. This might be attributed to the increase in oxygen transfer and mass transfer rates due to increased surface area of contact among media components [26]. Beyond this level, higher growth was achieved but accumulation of PHA was decreased that attributed to limitations of stress conditions required for PHA granules storage [31]. Wei et al., [32] reported maximum production of DCW and PHB production at agitation rate $200 \mathrm{rpm}$ by Cupriavidus denitrificans 184, while $175 \mathrm{rpm}$ was the optimal for Pseudomonases aregunoisa NCIM No. 2948 [30].

Supplementation of $0.5 \%$ methanol as an auxiliary carbon source to fermentation medium maximized PHA recovery yield of PHA to $50.72 \%(w / w)$ by strain Azu-IN1. This indicated that methanol is the principal precursor for PHA synthesis by strain Azu-IN1 as previously reported [33-34]. Besides, the recovery yield is superior to that obtained to Yezza et al., [35] who reported that, after $66 \mathrm{~h}$, a copolymer content of $30 \%(w / w)$ was achieved when $1 \%(v / v)$ methanol solution supplemented with $0.1 \%(v / v)$ valeric acid used as substrate. In addition, the yield $\left(Y_{\mathrm{p} / \mathrm{s}}\right)$ of 0.228 $\mathrm{g} / \mathrm{g}$ obtained in this study is about $84.5 \%$ of the maximum theoretical yield based on glycerol $(0.47 \mathrm{~g} / \mathrm{g})$ via acetyl-CoA pathway [22].

To achieve high product concentration, fed-batch fermentation has been conducted to reduce the effect of high initial substrate concentration. Different feeding strategies were applied. Amongst all, feeding with glycerol $(0.5 \%)$, phosphorus $(0.15$ $0.05 \%)$ and ammonium chloride $(0.05 \%)$ achieved the highest production of DCW at $6.05 \mathrm{~g} / \mathrm{L}, \mathrm{PHA}$ at $3.73 \mathrm{~g} / \mathrm{L}$ and recovery yield at $61.65 \%(w / w)$ after $72 \mathrm{~h}$. The obtained PHA production and PHA recovery yield are about $28 \%$ and $22.6 \%$ increase in when compared to that obtain by batch fermentation with $2.65 \mathrm{~g} / \mathrm{L}$ and $50.27 \%$, respectively. This indicated that this feeding regimen supported both cell growth and PHA accumulation during growth by strain Azu-IN1. Zhu et al., [36] achieved $7.4 \mathrm{~g} / \mathrm{L}$ of PHB with $31.4 \%$ recovery yield by Burkholderia cepacia ATCC 17759 in fed batch fermentation from glycerol after at $120 \mathrm{~h}$. Cui et al., [37] reported maximum $\mathrm{PHB}$ of $11.5 \mathrm{~g} / \mathrm{L}$ with recovery of $46.6 \%$ of DCW, $(w / w)$ after $30 \mathrm{~h}$ in fed-batch fermentation by Chelatococcus daeguensis. Although the results achieved in this study is superior to all previously reported studies, the concentration of PHA production is required to be further improved. Further investigations on repeated batch studies with cell recycle will be conducted to enhance cell growth and PHA accumulations. Up to the authors knowledge, this is the first study on PHA production by Zobellella taiwanensis by utilization of glycerol as the sole carbon source.

\section{CONCLUSION}

In the present report, PHAs production and optimization using glycerol as substrate was performed using a new isolate, Zobellella taiwanensis Azu-IN1 strain at $37^{\circ} \mathrm{C}$. Glycerol at $1 \%(v / v)$; ammonium chloride, $1 \mathrm{~g} / \mathrm{L}$; methanol. $0.5 \%$; $\mathrm{pH}, 6.5$; and agitation rate, $200 \mathrm{rpm}$ were the optimal fermentation conditions for PHA production by Azu-IN1 strain. Under these conditions, maximum PHA production of $2.65 \mathrm{~g} / \mathrm{L}$ with recovery yield of $50.27 \%(w / w)$ were achieved after $36 \mathrm{~h}$ in batch fermentation. Fed batch fermentation based on feeding solution containing glycerol, phosphorus and ammonium chloride resulted in improved production $(3.73 \mathrm{~g} / \mathrm{L})$ and recovery yield $(61.65 \%$ of $\mathrm{DCW}, w / w)$.

\section{Financial support and sponsorship: Nil.}

Conflict of Interests: There are no conflicts of interest.

\section{REFERENCES}

1. Wong SL, Ngadi N, Abdullah TAT, Inuwa IM. Current state and future prospects of plastic waste as source of fuel: A review. Renewable and Sustainable Energy Reviews. 2015; 50: 1167-1180.

2. Ray S, Prajapati V, Patel K, Trivedi U. Optimization and characterization of PHA from isolate Pannonibacter phragmitetus ERC8 using glycerol waste. International journal of biological macromolecules. 2016; 86: 741-749.

3. Salehizadeh H, Loosdrecht MCMV. Production of polyhydroxyalkanoates by mixed culture: recent trends and biotechnological importance. Biotechnology Advances. 2004; 22: 261-279.

4. Castilho LR, Mitchell DA, Freire DMG. Production of polyhydroxyalkanoates from waste materials and by-products by submerged and solid-state fermentation. Bioresource Technology. 2009; 100(23): 5996-6009.

5. Bugnicourt E, Cinelli P, Lazzeri A, Alvarez V. Polyhydroxyalkanoate: Review of synthesis, characteristics, processing and potential applications in packaging. Express Polymer Letters. 2014; 8 (11): 791-808.

6. Muhammadi S, Muhammad A, Shafqat, H. Bacterial polyhydroxyalkanoates-eco-friendly next generation plastic: Production, biocompatibility, biodegradation, physical properties and applications. Green Chemistry Letters and Reviews. 2015; 8(3-4): 56-77.

7. Anjum A, Zuber M, Mahmood, ZK, Noreen, A, Naveed A and Tabasum, S. Microbial production of polyhydroxyalkanoates and its copolymers. International Journal of Biological Macromolecules. 2016; 89:161-174. 
8. Ahn WS, Park SJ, Lee SY. Production of poly (3-hydroxybutyrate) from whey by cell recycle fed-batch culture of recombinant Escherichia coli. Biotechnology Letter. 2001; 23: 235-240.

9. da Silva GP, Mack M, Contiero J. Glycerol: A promising and abundant carbon source for industrial microbiology. Biotechnology Advances. 2009; 27(1): 30-9.

10. Du C, Sabirova J, Soetaert W, Lin SKC. Polyhydroxyalkanoates production from low-cost sustainable raw materials. Current Chemical Biology. 2012; 6(1): 14-25.

11. Spiekermann P, Rehm B, Kalscheuer R. A sensitive, viable-colony staining method using Nile red for direct screening of bacteria that accumulate polyhydroxyalkanoic acids and other lipid storage compounds. Archives of Microbiology. 1999; 71: 73-80.

12. Abdel-Rahman MA. Establishment of efficient cellulolytic bacterial consortium potential for designed composting of rice straw. International Journal of Advanced Research in Biological Science. 2016; 3(4): 211228.

13. Kuhn J, Müller H, Salzig D, Czermak P. A rapid method for an offline glycerol determination during microbial fermentation. Electronic Journal of Biotechnology. 2015; 18(3): 252-255.

14. Sathianachiyar S, Devaraj A. Biopolymer production by bacterial species using glycerol, aby product of biodiesel. International Journal of Scientific and Research Publications. 2013; 3(8): 1-5.

15. Silverstein R, Bassler G, Morrill T. Spectrometric identification of organic compounds, $5^{\text {th }}$ ed. John Wiley \& Sons, INC, New York. 1991

16. Gorenflo V, Steinbüchel A, Marose S. Quantification of bacterial polyhydroxy-alkanoic acids by Nile red staining. Applied Microbiolology and Biotechnology. 1999; 51:765-772.

17. Ibrahim MHA, Steinbüche A. Zobellella denitrificansstrain MW1. a newly isolated bacterium suitable for poly (3hydroxybutyrate) production from glycerol. Journal of Applied Microbiology. 2010; 108(1): 214-225.

18. El-Abd MA, El-Sheikh HH, Desouky S, Shehab A. Identification, Biodegradation and bio-evaluation of biopolymer produced from Bacillus thuringenesis. Journal of Applied Pharmaceutical Science. 2017; 7 (04): 103-110.

19. Sindhu R, Ammu B, Binod P, Deepthi SK, Ramachandran, K B, Soccol, $\mathrm{C}$ R, Pandey, A. Production and characterization of poly-3hydroxybutrate from crude glycerol by Bacillus spharaeicus NII 0838 and improving its thermal properties by blending with other polymers. Brazilian archives of Biology and Technology. 2011; 54(4): 783-794.

20. Chanasit W, Hodgson B, Sudesh K, Umsakul K. Efficient production of polyhydroxyalkanoates from Pseudomonas mendocina PSU using a biodiesel liquid waste (BLW) as the sole carbon source. Bioscience, biotechnology, and biochemistry. 2016; 80(7): 1440-1450.

21. de Castro JS, Nguyen LD, Seppala J. Bioconversion of commercial and waste glycerol into value-added polyhydroxyalkanoates by bacterial strains. Journal of Microbial \& Biochemical Technology. 2014; 6(6): $337-345$.

22. de Paula FC, Kakazu S, de Paula CBC, Gomez JGC, Contiero J. Polyhydroxyalkanoate production from crude glycerol by newly isolated Pandoraea sp. Journal of King Saud University-Science. 2017; 29(2), 166-173.

23. Beaulieu M, Beaulieu Y, Mélinard J, Pandian S, Goulet J. Influence of ammonium salts and cane molasses on growth of Alcaligenes eutrophus and production of polyhydroxybutyrate. Applied and Environmental Microbiology. 1995; 61(1): 165-169.

24. Aramvash A, Akbari SZ, Dashti AS, Ghafari, MD. Statistical physical and nutrient optimization of bioplastic polyhydroxy butyrate production by Cupriavidus necator. International Journal of Environmental Science and Technology. 2015; 12(7):2307-2316.
25. Dashti AS, Aramvash A. One-Factor-at-a-Time Optimization of Polyhydroxybutyrate Production and Growth of Alcaligenes eutrophus by Altering Culture Parameters and Incubation Time. Journal of Sciences. 2015; 26(4): 303-313.

26. Sasidharan RS, Bhat, SG, Chandrasekaran M. Biocompatible polyhydroxybutyrate production by marine Vibrio azureus BTKB33 under submerged fermentation. Annals of microbiology. 2015; 65 (1): 455-465.

27. Kalaiyezhini D, Ramachandran KB. Biosynthesis of poly-3hydroxybutyrate from glycerol by Paracoccus denitrificansin a batch bioreactor: Effect of process variables. Preparative Biochemistry and Biotechnology. 2015; 45(1): 69-83.

28. Ramadas NV, Singh SK, Socool C R, Pande A. Polyhydroxylbutrate production using agro-industrial residue as substrate by Bacillus sphaericus NCIM 5149. Brazilian archives of Biology and Technology. 2009; 52(1): 17-23.

29. Sharma P, Bajaj BK. Cost-effective substrates for production of-poly- $\beta$ hydroxybutrate by a newly isolated Bacillus cereus PS-10. Journal of environmental biology. 2015; 36: 1297-1304.

30. Tripathi AD, Yadav A, Jha A, Srivastava SK. Utilizing of sugar refinery waste (Cane Molasses) for production of bio-plastic under submerged fermentation process. Journal of Polymers and the Environment. 2012; 20: 446-453.

31. Serafim LS, Lemos PC, Albuquerque MGE, Reis MAM. Strategies for PHA production by mixed cultures and renewable waste materials. Applied microbiology and biotechnology. 2008; 81(4), 615-628.

32. Wei YH, Chen WC, Huang CK, Wu HS, Sun YM, Lo CW. Screening and evaluation of polyhydroxybutyrate-producing strains from indigenous isolate Cupriavidus denitrificans strains. International journal of molecular sciences. 2011; 12(1): 252-265.

33. Braunegg G, Genser K, Bona R, Haage G, Schellauf F, Winkler E. Production of PHAs from agricultural waste material. In: Macromolecular Symposia (Vol 144, No 1, pp 375-383) WILEY-VCH Verlag GmbH \& Co KGaA. 1999.

34. Dobroth ZT, Hu S, Coats ER, McDonald AG. Polyhydroxybutyrate synthesis on biodiesel wastewater using mixed microbial consortia. Bioresource Technology. 2011; 102(3): 3352-3359.

35. Yezza A, Fournier D, Halasz A, Hawari J. Production of polyhydroxyalkanoates from methanol by a new methylotrophic bacterium Methylobacterium sp GW2. Applied Microbiology and Biotechnology. 2006; 73: 211-218.

36. Zhu C, Nomura CT, Perrotta JA, Stipanovic AJ, Nakas AP. Production and characterization of poly-3-hydroxybutyrate from biodiesel-glycerol by Burkholderia cepacia ATCC 17759. Biotechnology progress. 2010; 26(2):424-430.

37. Cui B, Huang S, Xu F, Zhang R, Zhang Y. Improved productivity of poly (3-hydro xybutyrate) (PHB) In thermophilic Chelatococcus daeguensis TAD1 using glycerol as the growth substrate in a fed-batch culture. Applied microbiology and biotechnology. 2015; 99(14):6009-6019.

\section{How to cite this article:}

Abdel-Rahman MA, Desouky SE, Azab MS, Esmael ME. Fermentative Production of Polyhydroxyalkanoates (PHAs) from Glycerol by Zobellella taiwanensis Azu-IN1. J App Biol Biotech. 2017; 5 (05): 16-25. 


\section{Supplementary Data}
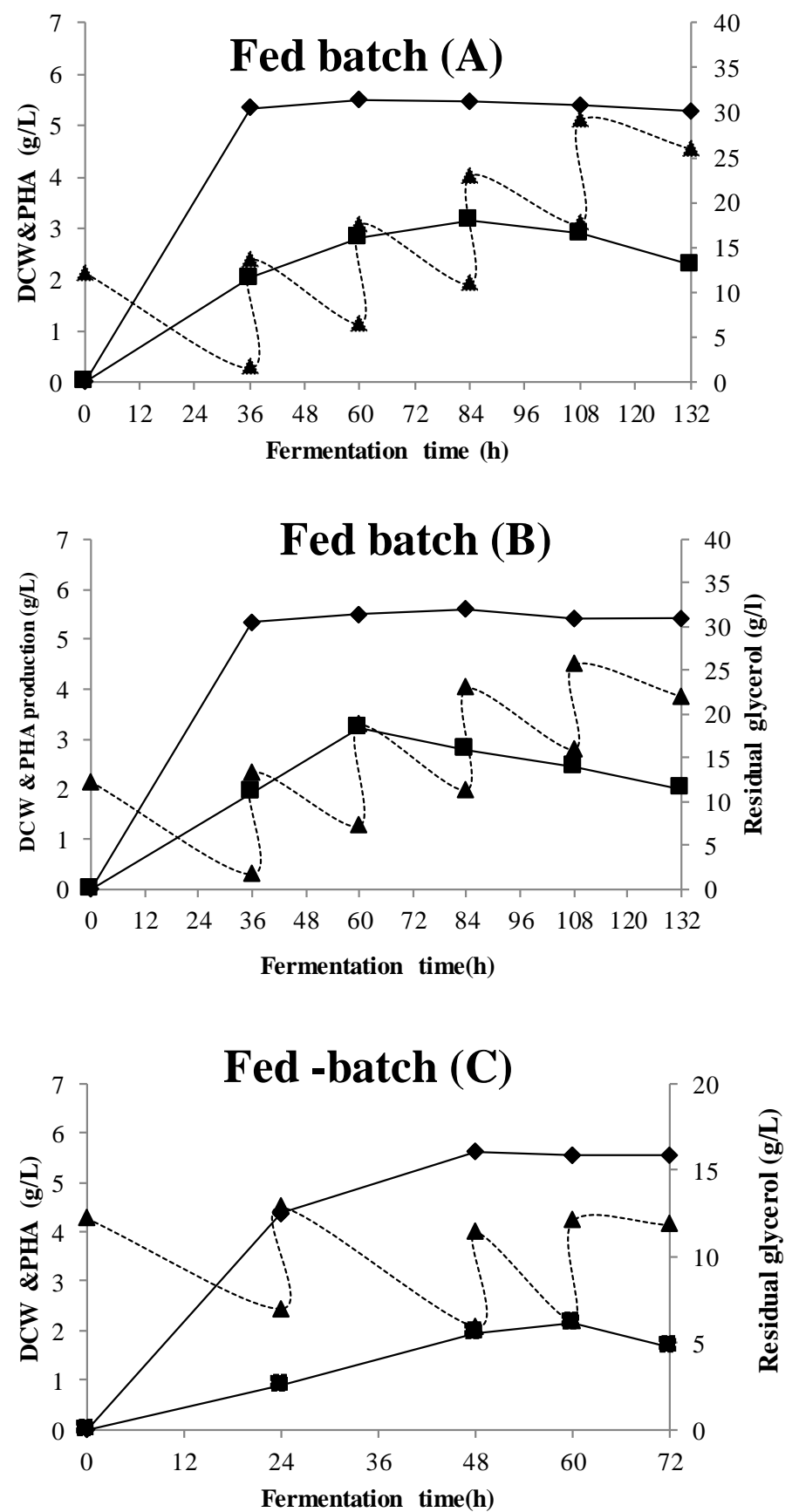

Fig. S1: Fed batch fermentation with different feeding strategies for PHA production from glycerol by Zobellella taiwanensis Azu-IN1 at $37^{\circ} \mathrm{C}$, initial $\mathrm{pH} 6.5$ and agitation rate $200 \mathrm{rpm}$. 